\title{
PERANAN WAKAF PRODUKTIF PEMUDA MUHAMMADIYAH UNTUK KESEJAHTERAAN WARGA DESA LONGKEYANG, BODEH, PEMALANG
}

\author{
Amirul Bakhri ${ }^{1}$ \\ Sekolah Tinggi Ilmu Tarbiyah (STIT) Pemalang \\ Email: bahri_amir@ymail.com
}

\begin{abstract}
One of the forms of worship to draw closer to Allah SWT related to property is donated. waqf istismari also called productive waqf, waqf property that is used for investment purposes, whether in agriculture, industry, trade, and services. This endowment is growing problems in the village Longkeyang, where the youth of Longkeyang attempted endowment for the welfare of citizens. In 2006, approximately 10 people from the youth of the Longkeyang together activists AMM (Angkatan Muda Muhammadiyah) began a new initiative is to create a new institution that was later (in 2010) was named after the Badan Pekerja Pengembangan Ranting Muhammadiyah (BP2RM). (1) The first step movement endowment productive Muhammadiyah Youth in Longkeyang namely (a) the anxiety of citizens and youth of the organization is stagnant and also go hand in hand some scholars who died, so no worries "if shortly Muhammadiyah in Longkeyang will run out" as the scorn of other people. (B) Establish Badan Pekerja Pengembangan Ranting Muhammadiyah (BP2RM) Longkeyang village. (C) Movement Endowments Endowments coins For Productive. The two (2) Management of communal ownership of productive Youth in Longkeyang namely (a) From the collected coins donated land and then bought 1,500 m maximized as initial capital. (B) The existing endowments worked together to reduce the cost of key crops albasia timber, then the cost of treatment using the results of intercropping banana plants. The third (c) In the future, earning endowment will be managed by the sharing system, since from 2006 to 2010 the endowment of productive trees used for the expansion of land. (3) The Role of Waqf Productive Youth Welfare Citizens For The Longkeyang namely (a) The results
\end{abstract}

1 Penulis adalah Dosen Sekolah Tinggi Ilmu Tarbiyah (STIT) Pemalang. Tulisan ini merupakan hasil penelitian penulis yang didapat dari bantuan penelitian DIKTIS Kementerian Agama RI tahun 2016. 
of this productive endowments, are not significant, but citizens can already feel as waqf land managers and also from the results of the banana crop intercropping. (B) Some of the programs that have resulted from the productive management of waqf endowments suppl shroud support fund for volunteers who want to stay.

Keywords: Endowments, Awqaf Productive, Youth of Muhammadiyah.

\section{A. Pendahuluan}

Islam yang bersumber pada dua pokok yaitu Alquran dan Hadits Nabi SAW adalah suatu agama yang lengkap, sempurna, universal dan berlaku untuk segala zaman dan tempat. Sebagai, ajaran ia dipandang suci oleh pemeluknya. Dari sisi lain, setiap pemeluk agama akan berusaha mewujudkan ajaran agamanya ke dalam tingkah laku keberagamaan sebagai aktualisasi ajaran. Salah satu dari bentuk ibadah untuk mendekatkan diri pada Allah SWT yang berkaitan dengan harta benda adalah wakaf. Amalan wakaf sangat besar artinya bagi kehidupan sosial ekonomi, kebudayaan dan keagamaan. Oleh karena itu, Islam meletakkan amalan wakaf sebagai salah satu macam ibadah yang amat digembirakan. Hal ini sebagaimana yang difirmankan Allah SWT dalam surat Ali Imran ayat 92, adalah sebagai berikut:

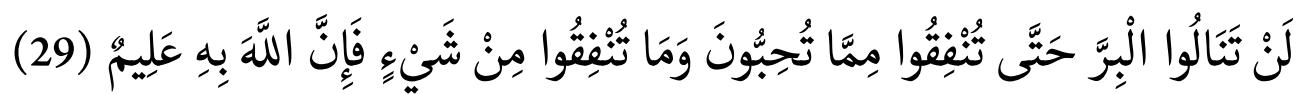

Artinya: "Kamu sekali-kali tidak akan sampai kepada kebaikan (yang sempurna) sebelum kamu menafkahkan sebagian harta yang kamu cintai. Dan apapun yang kamu nafkahkan, maka Allah mengetahuinya". (Q.S. Ali Imran: 92)

Dari segi penggunaannya, wakaf dapat dibedakan menjadi wakaf mubasyir dan wakaf istismari. Wakaf mubasyir adalah harta wakaf yang menghasilkan pelayanan masyarakat dan bisa digunakan secara langsung seperti madrasah dan rumah sakit. Sedangkan wakaf istismari adalah harta wakaf yang ditujukan untuk penanaman modal dalam produksi barang-barang dan pelayanan yang dibolehkan syara' dalam bentuk apapun kemudian hasilnya diwakafkan sesuai keinginan wakif. Wakaf istismari biasa disebut juga wakaf produktif, yaitu wakaf harta yang digunakan untuk kepentingan investasi, baik di bidang pertanian, perindustrian, perdagangan, dan jasa. Manfaat pada wakaf produktif tidak diperoleh dari benda wakaf secara langsung, melainkan dari keuntungan atau hasil pengelolaan wakaf.

Kata produktif merupakan kata sifat yang berasal dari kata produk yang berarti hasil, hasil kerja, barang atau benda yang dihasilkan. Berdasarkan makna tersebut, kata produktif memiliki pengertian sesuatu yang memiliki daya hasil atau mempunyai kemampuan untuk menghasilkan (dalam jumlah besar). Makna lain dari kata produktif adalah subur. Jaih Mubarok mengartikan wakaf produktif sebagai proses pengelolaan benda wakaf untuk menghasilkan barang atau jasa yang maksimum dengan modal yang minimum. Menurut Mubarok, wakaf produktif dikelola dengan pendekatan bisnis, yakni suatu usaha yang berorientasi pada keuntungan dan keuntungan tersebut disedekahkan kepada pihak yang berhak menerimanya. Tujuan utama bisnis adalah laba atau keuntungan melalui berbagai usaha yang mampu 
menghasilkan barang dan jasa yang dibutuhkan masyarakat. Berbagai usaha yang termasuk kegiatan bisnis meliputi usaha pertanian, produksi, konstruksi, distribusi, transportasi, komunikasi, dan usaha jasa. ${ }^{2}$

Permasalahan wakaf ini pun berkembang di desa Longkeyang, dimana pemuda Muhammadiyah Longkeyang berusaha melakukan wakaf untuk kesejahteraan warga. Pada tahun 2006, kurang lebih 10 orang dari pemuda Muhammadiyah di Longkeyang bersama para aktivis AMM (Angkatan Muda Muhammadiyah) mulai merintis sebuah ikhtiar baru yaitu dengan membuat lembaga baru yang kemudian (pada tahun 2010) dinamai Badan Pekerja Pengembangan Ranting Muhammadiyah (BP2RM). Padahal warga Muhammadiyah di sana kurang lebih berjumlah $30 \mathrm{KK}$.

Awal mula gerakan wakaf produktif yang dilakukan adalah menggalang iuran AMM Longkeyang dan sedekah abadi bagi alumni Ortom di luar Longkeyang yang mendukung gerakan ini. Serta melakukan efisiensi setiap keping/kertas uang yang masuk ke Persyarikatan. Setiap bulan Ramadhan TPQ Al Manar (milik PRM) biasa mendapat dana bisaroh dari Pemda Pemalang sebesar Rp. 650.000/per tahun untuk para ustadz/ustadzahnya. Para ustadz/ ustadzahnya dari AMM hanya mau menerima sebagian kecil dari dana bantuan itu. Selebihnya diatas Rp. 500.000,- dijadikan dana abadi untuk membeli tanah untuk Ranting Muhammadiyah. Bersamaan dengan itu, anak-anak muda ini juga memulai gerakan wakaf pohon bagi warga/ simpatisan dan mengelola aset wakaf tanah seluas $1.000 \mathrm{M}^{2}$ milik Ranting yang selama ini terbengkelai dan tidak terurus yaitu dengan menanaminya pohon Albasia. Gerakan ini terus bergulir dan mendapatkan apresiasi yang memadai. ${ }^{3}$

Dari beberapa uraian tersebut di atas, penulis tertarik untuk mengkaji dan menganalisa Peranan Wakaf Produktif Pemuda Muhammadiyah Untuk Kesejahteraan Warga Desa Longkeyang, Kecamatan Bodeh, Kabupaten Pemalang, sehingga akan menjadi lebih jelas bagaimana awal mula pembentukan gerakan wakaf serta bagaimana pengelolaan wakaf tersebut sehingga bisa mensejahterakan masyarakat.

\section{B. Tinjauan Umum Tentang Wakaf}

\section{Pengertian Wakaf}

Menurut bahasa wakaf berasal dari waqf yang berarti radiah (terkembalikan), al-tahbis (tertahan), al-tasbil (tertawan) dan al-man'u (mencegah). Sedangkan menurut istilah, terdapat beberapa pendapat, salah satunya wakaf menurut Hendi Suhendi yang adalah menahan sesuatu benda yang kekal zatnya, dan memungkinkan untuk diambil manfaatnya guna diberikan di jalan Allah. ${ }^{4}$ Sedangkan Suryana Dkk mengatakan bahwa Wakaf adalah menahan harta dan memberikan manfaatnya di jalan Allah, sebagai sarana mendekatkan diri kepada Allah yang ganjarannya tidak terbatas sepanjang pewakaf itu hidup, tetapi terbawa sampai ia meninggal

2 Jaih Mubarok, 2008, Wakaf Produktif, Bandung: Simbiosa Rekatama Media.

3 Wawancara dengan Bpk Casroni sebagai inisiator gerakan wakaf produktif di Longkeyang, 10 Mei 2016, di Desa Longkeyang.

4 Hendi Suhendi, 2008. Fiqih muamalah. PT Rajagrafindo Persada. Jakarta, hlm. 239. 
dunia. ${ }^{5}$ Adapun Ali MD mengatakan Wakaf adalah salah satu lembaga yang dianjurkan oleh ajaran Islam untuk dipergunakan oleh seseorang sebagai sarana penyaluran rezeki yang diberika oleh Allah kepadanya. ${ }^{6}$

Sedangkan wakaf dalam pandangan ahli fiqih di dalam buku yang ditulis Kementerian Agama Bimas Islam mengutip beberapa pendapat ahli fiqih ${ }^{7}$ :

Menurut Imam Hanafi, wakaf adalah menahan suatu benda yang menurut hukum, tetap milik si wakif dalam rangka mempergunakan manfaatnya untuk kebajikan. Berdasarkan definisi itu maka pemilikan harta wakaf tidak lepas dari si wakif, bahkan ia dibenarkan menariknya kembali dan ia boleh menjualnya. Jika si wakif wafat, harta tersebut menjadi harta warisan buat ahli warisnya.

Menurut Madzhab Maliki bahwa wakaf itu tidak melepaskan harta yang diwakafkan dari kepemilikan wakif, namun wakaf tersebut mencegah wakif melakukan tindakan yang dapat melepaskan kepemilikannya atas harta tersebut kepada yang lain dan wakif berkewajiban menyedekahkan manfaatnya serta tidak boleh menarik kembali wakafnya. Perbuatan si wakif menjadikan manfaat hartanya untuk digunakan oleh mauquf bih (penerima wakaf), walaupun yang dimilikinya itu berbentuk upah, atau menjadikan hasilnya untuk dapat digunakan seperti mewakafkan uang.

Menurut Madzhab Syafi' dan Imam Hanbali, bahwa wakaf adalah melepaskan harta yang diwakafkan dari kepemilikan wakif, setelah sempurna prosedur perwakafan. Wakif tidak boleh melakukan apa saja terhadap harta yang diwakafkan, seperti: perlakuan pemilik dengan cara memindahkan kepemilikannya kepada yang lain, baik dengan tukaran (tukar menukar) atau tidak. Jika wakif wafat, harta yang diwakafkan tersebut tidak dapat diwarisi oleh ahli warisnya. Wakif menyalurkan manfaat harta yang diwakafkannya kepada mauquf'alaih (yang diberi wakaf) sebagai sedekah yang mengikat, dimana wakif tidak dapat melarang penyaluran sumbangannya tersebut.

Adapun wakaf menurut Abu Bakar Muhammad bin Al-Sakhrazi:



Artinya: "Penahanan harta yang memungkinkan untuk dimanfaatkan desertai dengan kekal zatl benda dengan memutuskan (memotong) tasharruf (penggolongan) dalam penjagaannya atas Mushrif (pengelola) yang dibolehkan adanya ${ }^{8}$

Dari definisi yang ada di atas, bahwa wakaf merupakan sebuah harta atau suatu benda yang

5 Suryana, A. T., Alba, C., Syamsudin, E., \& Asiyah, U, 1996. Pendidikan Agama Islam untuk Perguruan Tinggi. Bandung: Tiga Mutiara, hlm. 131.

6 Ali, M. D. 1988. Sistem Ekonomi Islam Zakat dan Wakaf. Jakarta: UI-Press, hlm. 80.

7 Kememterian Agama Bimas Islam, 2013. Paradigma Baru Wakaf di Indonesia. Jakarta, hlm. 1-4

8 Abi Bakr Muhammad Ibn al Syarkhasi, t.th, Kitab Al-Mabsuth, Beirut: Dar al Kutub al-Ilmyah, Jld. IV Juz XII, hlm. 33 . 
diwakafkan oleh wakif (orang yang mewakafkan) kepada mauquf 'alaih (yang diberi wakaf) dengan memindahkan kepemilikan untuk umat, dimana harta atau benda yang diwakafkan bersifat kekal dan dimanfaatkan sebagai saran mendekatkan diri kepada Allah untuk kemaslahatan umat yang ganjarannya terbawa sampai si pewakaf meninggal dunia.

\section{Dasar Hukum Wakaf}

Wakaf ini merupakan salah satu anjuran dalam agama Islam yang sangat luar biasa manfaat nya untuk kemaslahatan umat yang terdapat kandungan nya di dalam Alquran dan hadis Nabi Saw. Di dalam Alquran sering menyatakan konsep wakaf dengan ungkapan yang menyatakan tentang infaq demi kepentingan umum. Sedangkan dalam hadist sering kita temui ungkapan wakaf dengan ungkapan habs (tahan), Shadaqah Jariyah.

a. Al Quran

Berikut ini adalah beberapa anjuran wakaf yang terdapat dalam Alquran:

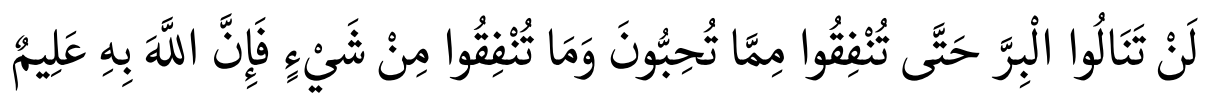

Artinya: "Kamu sekali-kali tidak sampai kepada kebajikan (yang sempurna), sebelum kamu menafkahkan sebahagian harta yang kamu cintai. Dan apa saja yang kamu nafkahkan, maka sesungguhnya Allah mengetahuinya." (Q.S. Ali Imran: 92)

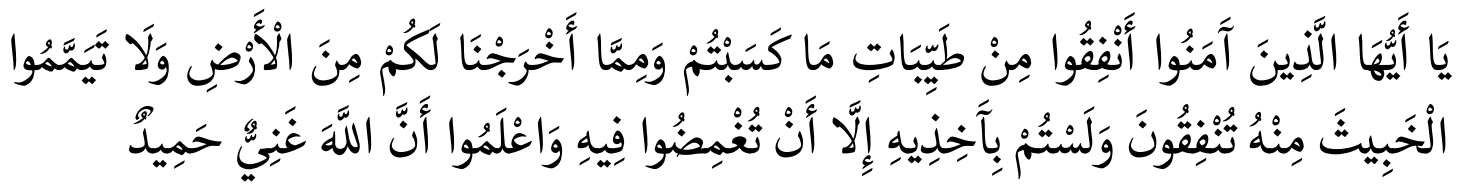

Artinya: "Hai orang-orang yang beriman, nafkahkanlah (di jalan Allah) sebagian dari hasil usahamu yang baik-baik dan sebagian dari apa yang Kami keluarkan dari bumi untuk kamu. Dan janganlah kamu memilih yang buruk-buruk lalu kamu menafkahkan daripadanya, padahal kamu sendiri tidak mau mengambilnya melainkan dengan menicingkan mata terhadapnya. Dan Ketahuilah, bahwa Allah Maha Kaya lagi Maha Terpuji.” (Q.S AlBaqarah, $2: 267)$

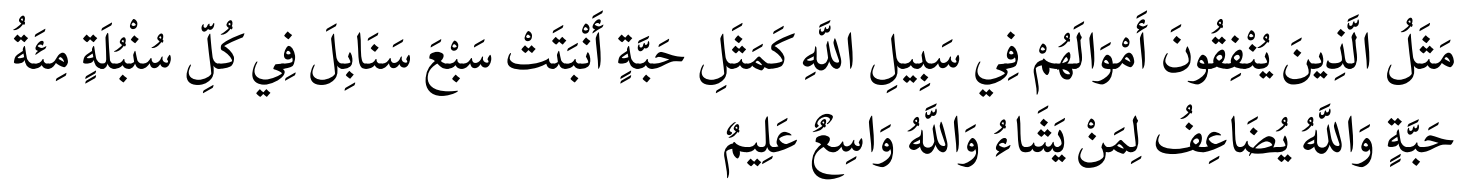

Artinya: "Perumpamaan (nafkah yang dikeluarkan oleh) orang-orang yang menafkahkan hartanya di jalan Allah adalah serupa dengan sebutir benih yang menumbuhkan tujuh butir, pada tiap-tiap butir: seratus biji. Allah melipatgandakan (ganjaran) bagi siapa yang Dia kehendaki. Dan Allah Maha luas (kurnia-Nya) lagi Maha Mengetahui."(Q.S. Al-Baqarah: 261)

b. Hadis Nabi Saw

Di dalam hadist ada banyak hadsit tentang wakaf dengan aneka ungkapan kata (shadaqah jariah, habs, shadaqah). Berikut ini beberapa hadis Nabi Saw tentang anjuran berwakaf untuk umat: 


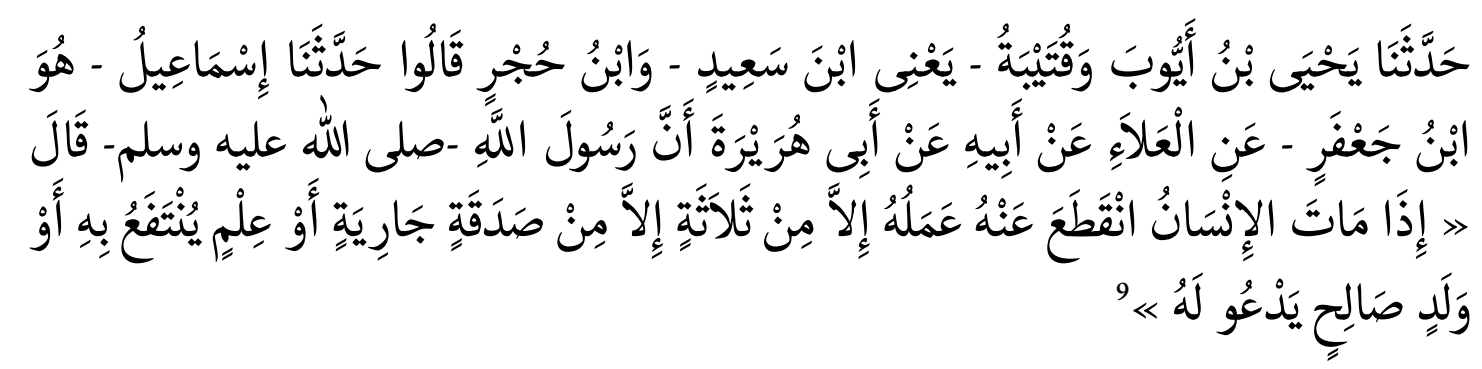

Artinya: "Menceritakan kepada kami Yahya bin Ayyub dan Qutaibah yakni Ibnu Said dan Ibnu Hujr berkata menceritakan kepada kami Ismail (Ibnu Ja'far) dan al-Ala' dari ayah nya, dari Abu Hurairah, bahwa Rasulullah Saw berkata: apabila manusia meninggal dunia, terputus lah segala amal nya kecuali tiga hal: shadaqah jariyah, ilmu yang bermanfaat dan anak shalih yang mendoakan orang tuanya" (HR. Muslim) $)^{10}$

Hadits Nabi yang secara tegas menyinggung dianjurkannya wakaf, yaitu perintah Nabi Saw kepada Umar bin Khattab untuk mewakafkan tanahnya yang ada di Khaibar:

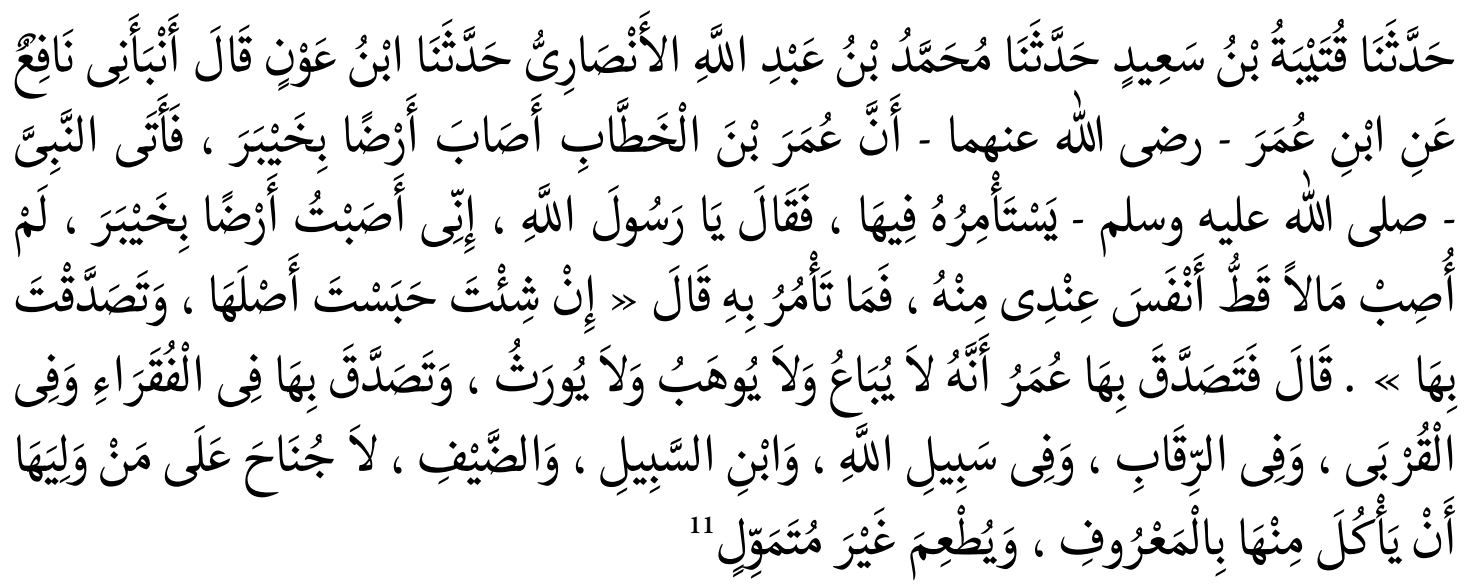

Artinya: "Menceritakan kepada kami Qutaibah bin Said menceritakan kepada kami Muhammad bin Abdullah al-Anshari, menceritakan kepada kami Ibnu Aun, berkata: member kabar kepada saya Nafi dari Ibnu Umar Ra bahwa Umar bin Khattab pernah mendapatkan sebidang tanah di Khaibar. Lalu, beliau mendatangi Nabi saw dan meminta nasehat mengenai tanah itu, seraya berkata, "Ya Rasulullah, saya mendapatkan sebidang tanah di Khaibar, yang saya tidak pernah mendapatkan harta lebih baik dari pada tanah itu". Nabi saw pun bersabda, "Jika engkau berkenan, tahanlah batang pohonnya, dan bersedekahlah dengan buahnya. Ibnu Umar berkata, "Maka bersedekahlah Umar dengan buahnya, dan batang pohon itu tidak dijual, dihadiahkan, dan diwariskan. Dan Umar bersedekah dengannya kepada orang-orang fakir, para kerabat, para budak, orang-orang yang berjuang di jalan Allah, Ibnu Sabil, dan para tamu. Pengurusnya boleh memakan dari hasilnya dengan cara yang makruf, dan memberikannya kepada temannya tanpa meminta harganya." (HR. Imam Bukhari) ${ }^{12}$

9 Imam Muslim, Shahih Muslim: Bab Ma Yalhaqu al-insan min al-Tsawab, Juz: 11, Hadis no. 4310, hlm. 68. 10 Terjemah dari Penulis sendiri.

11 Imam Bukhari, Shahih al-Bukhari: Bab al-Syuruth fil Waqaf, Juz: 10. Hadis no. 2737, hlm. 87

12 Terjemah dari Penulis sendiri 
c. Ijma' Sahabat

Para sahabat sepakat bahwa hukum wakaf sangat dianjurkan dalam Islam dan tidak satupun diantara para sahabat yang menafikan wakaf. sedangkan hukum wakaf menurut sahibul mazhab (Imam Abu Hanifah, Imam Malik, Imam Syaf'i dan Imam Ahmad bin Hambal) tidak dapat terdapat perbedaan yang signifikan. Menurut Imam Malik, Imam Syafi'i dan Imam Ahmad hukum wakaf adalah sunnah (mandub). Menurut Ulama Hanafiyah hukum wakaf adalah mubah (boleh). Sebab wakaf non muslim pun hukum wakafnya sah. Namun, demikian, wakaf nantinya bisa menjadi wajib apabila wakaf itu menjadi obyek dari Nazhir. ${ }^{13}$

\section{Tata Cara Perwakafan Tanah Di Indonesia}

Tata cara Perwakafan Tanah dan Pendaftarannya: (1) calon wakif harus melengkapi suratsurat yang diperlukan bagi perwakafan tanah yaitu sertifikat tanah, surat keterangan dari Kepala desa dan Camat bahwa tanah tersebut benar-benar milik wakif dan bebas dari sengketa. (2) wakif mengucapkan ijab kepada nadzir didepan kepala KUA dan dihadiri minimal dua orang saksi. (3) wakif yang tidak dapat hadir karena sakit parah dapat menuliskan ijabnya lalu di bacakan didepan nadzir dan kepala KUA. (4) Pejabat membuat Akta Ikrar wakaf. (5) kapala KUA atas mana nadzir mengajukan permohonan pendaftaran tanah wakaf kepada Bupati atau Kepala Daerah. (6) dengan telah didaftarkan dan dicatatnya tanah wakaf tersebut dalam sertifikat tanah milik yang diwakafkan, maka tanah wakaf itu telah mempunyai pembuktian yang kuat. ${ }^{14}$

\section{Pembahasan}

\section{Sejarah Desa Longkeyang, Bodeh, Pemalang}

Ada banyak Versi mengenai asal mula desa Longkeyang beberapa sesepuh menceritakan Longkeyang berasal dari kata Lo sejenis pohon ara atau Loa (ficus glomerata) yang banyak tumbuh di sebuah sungai kecil bernama "Kali Keyang" dinamakan demikian sebab jika musim hujan maka sungai tersebut akan tampak seperti melayang (Kleyang-Kleyang) diatas atap rumah jika dilihat dari bukit barat desa sehingga disebut desa LO-NG-KEYANG. Pada versi lain disebutkan bahwa Long berasal dari kata Kalong yang berarti berkurang ( bahasa Jawa : tidak dimaksudkan Hewan Kalong/ sejenis kelelawar besar) dan Kleyang artinya melayang barang siapa yang masuk wilayah ini dengan angkuh dan berniat jahat maka berkurang dan melayang kekuatannya.

Longkeyang merupakan desa dengan keadaan geografis berupa dataran tinggi, ketinggian tanahnya mencapai angka $265 \mathrm{M}$ dpl. Jumlah penduduk Desa Longkeyang per Maret 2016 adalah 3.753, yakni Laki-laki 1898, perempuan 1855 dimana terdapat 5 RT dan 25 RW. Adapun batas wilayah:

a. Sebelah selatan adalah desa Pagelaran

b. Sebelah barat desa Bodas yang keduanya secara administrasi masuk dalam kecamatan Watukumpul.

13 Departemen Agama RI, Pedoman Pengelolaan dan Pengembangan wakaf. Departemen Agama Islam Direktorat Jenderal Bimbingan Masyarakat Islam Direktorat Pemberdayaan Wakaf, Jakarta,2006, hlm 31

14 Syamsuri. 2004. Pendidikan Agama Islam. Jakarta: Erlangga, H. 180-181. 
c. Sebelah Utara desa Gunung batu, kecamatan Bodeh

d. Sebelah timur desa Jatingarang, kecamatan Bodeh. ${ }^{15}$

Dengan Luas wilayah Longkeyang 479.531 hektar, hampir 70\% merupakan dataran tinggi berupa tanah tegalan yang ditanami berbagai tanaman, dari pisang, cengkeh, mrica, kayu dan lain sebagainya. Sedangkan area tanah yang berupa lembah di bangun pemukiman penduduk dan sebagian lagi untuk lahan pertanian yang ditanami padi maupun jagung.

Ketika memasuki desa Longkeyang, dikanan kiri disuguhi pemandangan menakjubkan, dari hutan pinus, perkebunan kayu Sengon, cengkih, bahkan pesona pucukk gunung Slamet yang memanjakan pemandangan, berjejer dengan bukit- bukit indah menggugah banyak inspirasi dalam kehidupan. Ketika memasuki desa Longkeyang kita seakan- akan sedang berdiri atau bahkan terbang diatas awan, karena dari gerbang dukuh Sarangkadu, pintu masuk dari sebelah timur nampak perkampungan utama desa Longkeyang, seakan- akan kampung tersebut berada di tengah mangkuk, dihiasi dinding-dinding indah berupa perbukitan. Apalagi kalau memasuki desa Longkeyang dimalam hari, terlihat seperti bintang nampak indah dipandang dari ujung bukit, nampak terlihat kerlap-kerlip lampu di kota Pemalang, Kota Kajen dan sekitarnya.

\section{Tokoh Pemuda Penggerak Wakaf Produktif}

a. Mas Soleh

Satu tokoh muda desa Longkeyang yang satu ini merupakan alumni SMA Negeri 1 Pemalang, dan kini menjabat sebagai sekretaris desa Longkeyang, dan sebelumnya menjadi pejabat sementara. Di Muhammadiyah aktif sebagai sekretaris ranting, sementara juga menjdi pengurus Cabang Muhammadiyah Bodeh. Ungkapan yang khas dari tokoh yang satu ini adalah:

"Kita harus kayakan Ranting Muhammadiyah Longkeyang, Insya Allah Kita akan menjadi kaya, kalau kita kaya dulu barangkali kita menjadi lupa pada perjuangan lewat Muhammadiyab"

b. Darori

Ustad yang satu ini merupakan satu- satunya kader muda yang tersisa dari masa pendirian sampai sekarang. Kalimat yang senantiasa meluruskan arah perjuangan teman- teman pemuda adalah:

"Dari pengalaman saya sejak masa perintisan Ranting Muhammadiyah awal, dimana waktu itu saya masih remaja banyak hal yang terjadi, mewarnai perjalanan panjang Muhmmadiyah Longkeyang. Maka dari pengalaman itulah kita jangan sampai terjebak pada satu lubangyang sama"

c. Fakhruri

"Berangkat dari sejarah panjang, potensi yang dimilki, dan kelemahan yang kita milki, kita harus bangkit, bergerak maju. Kita mulai dari Menyatukan dan mengembangkan semua potensi, yang kedua kita bangun gerakan ekonomi yang kuat melalui wakaf produktif, yang ketiga kita harus siapkan kader yang unggul, militan, berkeinginan kuat membangun, mewjudkan Ranting yang Hebat"

15 Wawancara dengan mas Musoleh Pegawai Desa Longkeyang sekaligus pengurus Ranting Muhammadiyah Longkeyang tanggal 9 Oktober 2016 jam 13.00 


\section{Langkah Awal Gerakan Wakaf Produktif Pemuda Muhammadiyah Di Longkeyang}

Ranting Longkeyang termasuk salah satu Ranting teraktif. ${ }^{16}$ Setiap ada kegiatan, pimpinan baik di Cabang maupun Daerah selalu mendapat peran. Hanya saja kiprahnya didominasi orang-orang dari generasi tua. Program pengkaderan dan regenerasi tidak berjalan dengan baik. Satu-satunya kegiatan rutin yang menandakan masih adanya PRM Longkeyang adalah pengajian rutin bulanan yang dibina oleh PCM Bodeh. Walaupun berjalan rutin, kegiatan ini dapat dikatakan sebagai rutinitas alakadarnya. Kemasan kegiatannya kurang menarik dan gagal menggerakan anak-anak mudanya untuk bisa terlibat dalam Muhammadiyah.

Orang-orang di luar Muhammadiyah sering meledek kalau umur Muhammadiyah Longkeyang tinggal menunggu hari. Kalau semua generasi perintis itu wafat, maka tamat pula sejarah Muhammadiyah di Longkeyang. Saat ini, usia mayoritas generasi perintis dapat dikatakan itu sudah menjelang senja, selebihnya berusia Ashar. Ledekan-ledekan semacam ini terasa sangat menyakitkan, apalagi kalau pada kenyataannya mayoritas anak muda dari keluarga Muhammadiyah sendiri banyak yang tidak tertarik apalagi bersedia memenuhi panggilan suci untuk aktif di Muhammadiyah.

a. Membentuk Badan Pekerja Pengembangan Ranting Muhammadiyah (BP2RM) Desa Longkeyang

Di mulai dari tahun 2006, anak-anak muda Muhammadiyah di ranting Longkeyang bersama dengan para aktifis AMM yang sekarang menggawangi LPCR ${ }^{17}$ PDM $^{18}$ Pemalang, mulai merintis sebuah ikhtiar baru yaitu dengan membuat Badan Pekerja Pengembangan Ranting Muhammadiyah (BP2RM), dengan tugas pokok:

1) Mengkaji sejarah, potensi, masalah dan lain sebagainya yang berkaitan dengan maju dan mundurnya Muhammadiyah di ranting yang sudah kurang lebih 30 tahun berdiri,

2) Memproyeksikan program strategis pengembangan ranting setelah memahami sejarah, potensi, masalah dan lain sebagainya sehingga muncul program yang original, unik sesuai dengan potensi serta visioner,

3) Melaksanakan program secara bersama-sama dengan pimpinan ranting dan mengevaluasinya secara sederhana, periodik dan berkelanjutan. Salah satu program unnggulannya yg dilakukan adalah gerakan wakaf recehan untuk wakaf produktif kemudian wakaf pohon.

Badan yang dibentuk (BP2RM) ini bekerja selama dua puluh tahun (20 tahun). Kemudian badan ini, menyusun RencanaStrategis (Renstra) untukmengembangkan ranting Muhammadiyah Longkeyang. Tujuan penyusunan Renstra ini, (1) dimaksudkan untuk memberikan arah dan pedoman serta landasan bagi pemuda, warga dan simpatisan Muhammadiyah Desa Longkeyang dalam merumuskan dan melaksanakan kegiatan-kegiatan untuk mewujudkan cita-citanya, (2) agar pelaksanaan kegiatan-kegiatan dapat terarah, terpadu dan efektif untuk mencapai hasil

16 Mendapat Penghargaan dari Pimpinan Pusat Muhammadiyah sebagai Ranting Pilihan dari berbagai kategori yang diadakan tentang Cabang dan Ranting Pilihan di tahun 2012.

17 Lembaga Pengembangan Cabang dan Ranting.

18 Pimpinan Daerah Muhammadiyah. 
yang optimal dalam mewujudkan Ranting Muhammadiyah Desa Longkeyang berkembang dan maju dan (3) sebagai media untuk berkomunikasi kepada para donatur/dermawan warga dan simpatisan Muhammadiyah yang ada diluar Desa Longkeyang serta masyarakat dan lembaga pada umumnya yang ingin membantunya.

b. Gerakan Wakaf Recehan Untuk Wakaf Produktif

Awalnya iuran wakaf recehan dengan nominal minimal Rp.5.000,- karena anak-anak mudanya berpengahasilan kecil. Ada yang pengangguran, kuli bangunan, jualan bakso pikul, penjahit konveksi dan sebagainya. Tapi jangan diihat lima ribunya saja, akan tetapi dari lima ribu itulah anak-anak muda yang tadinya tidak memikirkan Muhammadiyah menjadi selalu ingat, minimal setiap bulan untuk iuran wakaf recehan. Wakaf recehan awalnya dikumpulkan setiap bulan, akan tetapi karena jumlah anak mudanya sedikit dan tersebar dibeberapa wilayah maka kemudian dikumpulkan ketika syawalan. Selain itu juga masing masing anggota membuka diri pada setiap orang barang kali ada yang mau bergabung atau membantu kegiatan wakaf recehan. Di samping itu, usaha penggalangan wakaf recehan ini dengan menulis di blog di internet dengan sederhana.

Setelah berhasil membeli wakaf pertama berupa tanah senilai tujuh juta (Harga tanah di Desa Longkeyang saat ini masih ada harganya dibawah $\mathrm{Rp} 10.000$ per m2). Gerakan wakaf recehan yang kemudian dibelikan tanah merupakan sebuah hal yang menurut Ali, M. D. (1988) dalam buku Sistem Ekonomi Islam Zakat dan Wakaf sudah sesuai yang dimaksud dengan harta yang diwakafkan (Mauquf), ${ }^{19}$ karena tanah bersifat kekal (kalau tidak ada musibah longsor dan sebagainya). Kemudian peserta gerakan wakaf recehan bertambah menjadi 30an pemuda Muhammadiyah. Kemudian mengembangkan wakaf pohon, bagi warga yang memiliki tanaman kayu mewakafkan beberapaa pohon. Sejak itu hampir seluruh warga Muhammadiyah Longkeyang baik yang mukim atau merantau ikut wakaf baik recehan maupun wakaf pohon. Ada juga yang wakaf lahan. Ada juga alumni IPM, IMM dari luar daerah yang ikut membantu. Jadi jumlah anggota gerakan wakaf produktif kurang lebih 100 orang.

Ada sebuah kisah menarik dari mas Fakhruri yakni "Kaleng Susu Berhadiah Wakaf” sebagai berikut:

Ini adalah satu dari banyak kisah yang terjadi dan mewarnai goresan sejarah Muhammadiyah Longkeyang. Pada waktu itu sekitar tahun 2010 dua aktifis muda Muhammadiyah Fakhruri dan Kholid berkunjung ke salah satu tokoh perintis Muhammadiyah Longkeyang yaitu Mbah Suwarno, sudah sering keduanya datang berdiskusi atau sekedar ngobrol dan medang (red: minum teh).

Pada malam itu Fakhruri memberi beberapa kaleng susu kepada Kholid dan dibawa kerumah mbah Suwarno sebagai oleh-oleh anak muda pada orang yang lebih sepuh (red: tua). Dan malam itupun seperti biasanya diisi obrolan santai dan diskusi kecil seputar desa dan kegiatan Muhammadiyah, wabil khusus progres gerakan wakaf recehan yang sedang digalakan para pemuda Muhammadiyah hingga akhirnya mbah Suwarno saking gembira dan trenyuh dari obrolan itu tentang gerakan dan cita-cita besar kedua 
anak muda itu hingga obrolan sedikit serius ketika mbah Suwarno mempertajam obrolan bahwa beliau sangat bangga pada gerakan yang anak muda bangun, dan citacitakan. Dan sebagai dukungan beliau mbah Suwarno berjanji akan mewakafkan sebidang tanah tegalan (kebun) ke Muhammadiyah. Alhamdulillah, berkah dari Allah kini wakaf dari mbah Suwarno sudah produktif dengan ditanami tanaman cengkeh yang setiap tahunnya panen, dan hasilnya masuk sebagai kas Wakaf Produktif. ${ }^{20}$

Hal lain yang menarik menurut mas Fakhruri, yakni setiap bulan Ramadhan, TPQ AlManar Longkeyang biasa mendapat dana bisaroh dari Pemda Pemalang sebesar Rp. 650.000,00 per tahun untuk para ustadz/ustadzahnya. Para ustadz/ustadzahnya dari AMM (Angkatan Muda Muhammadiya, seperti IPM, IMM, NA dan Pemuda Muhammadiyah) hanya mau menerima sebagian kecil dari dana bantuan itu. Selebihnya di atas Rp. 500.000,00, dijadikan dana abadi untuk membeli tanah milik Ranting. ${ }^{21}$

\section{Manajemen Pengembangan Wakaf Produktif Pemuda Muhammadiyah di Longkeyang}

Setelah gerakan wakaf recehan dilaksanakan, para pemuda mendesak agar wakaf yang ada seluas $1.500 \mathrm{~m}$ harus dimaksimalkan sebagai modal awal. Awalnya tanah wakaf yang ada, dan yang sudah dibeli digarap secara bersama-sama dengan begitu bisa menekan biaya dengan tanaman utama kayu albasia, dengan tumpang sari pisang. Setiap ada orang yang mau menjual tanahnya, akan dilihat keuangan yang ada kas wakaf produktif, apabila kurang maka pohon yang sudah besar ditebang dan uangnya untuk menambahkan melunasi tanah yang baru dibeli. Setelah memiliki lahan hampir tiga hektar maka kami menggunakan sistem bagi hasil, dengan penggarap adalah warga Muhammadiyah Longkeyang yang mau dan mampu mengelola dengan sistem bagi hasil.

Langkah nyata yang sudah berjalan selama lebih dua tahun (2 tahun) untuk membangun aset adalah pertama (1) dengan gerakan penanaman pohon albasia (sengon) yang dititipkan ditanah milik warga / simpatisan dan tanah wakaf milik Ranting Muhammadiyah luasnya 1750 $\mathrm{m}^{2}$ dengan cara bergotong-royong. Dan saat ini sudah menanam pohon albasia berjumlah tiga ratus (300) pohon lebih yang berusia rata-rata diatas dua tahun. Kedua (2) gerakan wakaf pohon pada warga dan simpatisan Muhammadiyah Desa Longkeyang seperti pohon Albasia, Cengkeh, Jati dan lainnya. Saat itu kita memilih dengan penanaman pohon albasia dengan pertimbangan sebagai berikut:

1. Hampir semua anggota/simpatisan Muhammadiyah petani dan memiliki lahan.

2. Pohon albasia sangat cocok ditanam didaerah pegunungan, mudah penanamannya, murah biaya perawatannya dan pohonnya cepat besar (cepat panen) yaitu kurang lebih lima tahun.

3. Permintaan akan kayu albasia, baik dalam maupun luar negeri sangat tinggi sehingga nilai ekonomisnya/harganya cukup baik.

20 Wawancara dengan mas Fakhruri Ketua BP2RM (Badan Pekerja Pengembangan Ranting Muhammadiyah) tanggal 9 Oktober 2016 jam 13.00.

21 Wawancara dengan mas Fakhruri Ketua BP2RM (Badan Pekerja Pengembangan Ranting Muhammadiyah) tanggal 9 Oktober 2016 jam 13.00 
Tanah yang diliki untuk saat ini oleh ranting Muhammadiyah Longkeyang, fokus ditanami tanaman kayu dan ditumpangsarikan (dicampur) dengan tanaman obat, pala pendem (seperti kapolaga, laos, kunyit dll). Untuk tanaman kayu waktu sekarang disamping menanam kayu Albasia juga dicampur kayu Jabon (lampeyan). Sehingga pada tanggal 24 Januari 2010 sudah menanam sebanyak 80 (delapan puluh) pohon Jabon. Adapun untuk tanaman obat mulai sekarang menanam dan mengumpulkan koleksi tanaman obat sebanyak-banyaknya. Disamping itu nantinya bersamaan bertambah tanah yang kita miliki ke depan rencana akan menanam tanaman industri lainnya seperti Coklat. Dari tanah wakaf seluas $+1750 \mathrm{~m} 2$, sebagian +750 $\mathrm{m} 2$ adalah dimilikinya dengan cara membeli dari hasil pengumpulan gerakan dana iuran abadi AMM Desa Longkeyang yaitu dibeli pada tanggal 17 Desember 2009.

Selain tanah wakaf dikelola dengan penanaman pohon albasia, jabon, tanah wakaf juga di tanami dengan tanaman sumpang sari. Hasil yang diperoleh ada dari tanaman tumpang sari yang jumlahnya kalau dirata-rata sekitar Rp.100.000,- perbulan. Dari hasil tumpang sari digunakan untuk biaya perawatan. Untuk panen cengkeh dari wakaf awal Rp. 2.500.000,- / tahun juga untuk biaya pembelian bibit, obat, dan perawatan. Untuk panen kayu sudah beberapa kali dengan nominal Rp. 3.000.000,- sampai dengan 15.000.000,-. Dari wakaf pohon dipanen untuk menambahi pembelian lahan wakaf, apabila ada kekurangan, akan ditambahi kas wakaf produktif yang ada. Jadi 100\% lahan tanah wakaf yang dibeli dari hasil panen tanah wakaf produktif yang berawal dari dari wakaf recehan.

Pada awal tahun 2011, BP2RM Longkeyang mampu membeli tanah lagi yang keempat dan juga pada pertengahan tahun 2011 membeli lagi tanah yang titik kelima serta ada seorang sesepuh (pendiri) Ranting mewakafkan tanahnya untuk Ranting Muhammadiyah Longkeyang. Pada tanggal 26 Maret 2012, Ranting Longkeyang membeli satu titik tanah lagi meskipun sedikit yang berdekatan dengan tanah milik Ranting Longkeyang lainnya. Hingga sampai tahun 2012, Ranting Longkeyang sudah mempunyai 7 titik tanah wakaf yang luasnya lebih $9.000 \mathrm{M}^{2}$ (hampir satu hektar) tanah wakaf produktif, yang diperoleh dengan cara membeli dari hasil gerakan wakaf uang, wakaf pohon, efisiensi dana yang masuk ke persyarikatan dan dari hasil pengelolaan aset wakaf produktif yang ada. Sedang aset yang lain berupa 3 batang pohon cengkeh umur 12 tahun, 12 batang pohon cengkeh umur 8 tahun, 80 batang pohon Albasia umur 4,5 tahun, 150 batang Albasia umur 5 tahun, dan 50 batang pohon Jabon umur 2 tahun serta aset wakaf uang tunainya lebih dari Rp 2,5 juta rupiah.

Usaha yang dilakukan selain dengan modal recehan, pemuda Muhammadiyah juga menulis artikel lewat blog di Internet. Kejadian yang tidak disangka dan diduga yakni sekitar bulan Agustus Tahun 2013, Pak Supardi dan Istrinya Ibu Nur'aeni, dimana keduanya bertempat tinggal di Bekasi menghubungi penulis artikel tersebut via telpon, yaitu Mas Roni Raska selaku Pembina BP2RM Longkeyang. Oleh Mas Roni Raska, Pak Supardi kalau mau mewakafkan wakaf produktif disarankan supaya langsung menghubungi Mas Fakhruri selaku Ketua BP2RM Longkeyang. Dalam hal ini, Mas Roni Raska juga mengingatkan pada Pak Supardi, jangan sekali-kali transfer uangnya sebelum beliau tahu betul dan percaya $100 \%$ pada Pimpinan Ranting Muhammadiyah Longkeyang. 
Keluarga Pak Supardi yang berasal dari Bekasi sebelumnya tidak mengenal sama sekali mengenai Ranting Muhammadiyah Longkeyang maupun para aktivis BP2RM Longkeyang. Pak Supardi, adalah pensiunan tenaga kesehatan di sebuah rumah sakit di Jakarta, Beliau beserta istrinya sejak pertengahan tahun 2013 sudah menyisihkan sebagian rezekinya, yang diniatkan untuk di sedekah dijalan Allah melalui wakaf produktif. Beliau sangat sadar, bahwa dana yang ada untuk wakaf produktif jumlahnya tidak begitu besar, maka kalau untuk membeli aset produktif lokasinya di kota tidak cukup dananya. Maka solusinya adalah harus mencari lokasi di desa, akhirnya beliau seaching minta bantuan lewat Googgle dibeberapa laman, beliau baca dan pelajari secara seksama. Akhirnya, setelah beliau membaca beberapa artikel di blog $w w w$. wakafproduktifmuhammadiyah.blogspot.co.id, beliau tertarik dan berniat akan wakaf produktif di Ranting Muhammadiyah Longkeyang Kecamatan Bodeh Kabupaten Pemalang Jateng.

Akhirnya, setelah terjadi komunikasi, pak Supardi menemui Pengurus BP2RM Longkeyang, Pimpinan Ranting dan Pimpinan Cabang, sekaligus melihat langsung tanah yang akan dibeli untuk diwakafkan pada Muhammadiyah. Singkat cerita, Pak Supardi akhirnya memutuskan pilihannya dan percaya pada PRM Longkeyang sebagai nadzir wakaf produktif keluarganya. Kemudian, berselang 3 hari selanjutnya setelah pak Supardi datang ke Longketang, beliau transfer uang sebesar Rp.73.000.000,00 pada Bendahara BP2RM Longkeyang untuk membeli tanah produktif seluas sekitar 0,5 Hektar di Desa Longkeyang. ${ }^{22}$

\section{Peranan Wakaf Produktif Pemuda Muhammadiyah untuk Kesejahteraan Warga di Longkeyang}

Gerakan wakaf produktif yang dilakukan pemuda Muhammadiyah di Longkeyang ini dikelola oleh BP2RM dan Pimpinan Ranting Muhammadiyah. Dimana hasil dari wakaf recehan yang digunakan untuk pembelian tanah dan perluasan tanah di garap oleh warga Muhammadiyah yang mau dan mampu mengelola dengan sistem bagi hasil sesuai dengan jenis tanaman. Untuk pengelolaan awal dilakukan secara bersama-sama seluruh warga Muhammadiyah. Perawatan dan pengobatan diambilkan dari hasil panen tanaman tumpang sari dan kas yang ada. Dan mulai tahun 2016 pengelolaan diserahkan pada penggarap dengan sistem bagi hasil. ${ }^{23}$

Pengelola dalam hal ini BP2RM dan PRM tidak mendapatkan bagian apapun, bahkan pertemuan apapun yang dilakukan, tidak menggunakan dan dari wakaf recehan maupun hasil panen wakaf produktif. Hal ini karena setiap hasil panen yang didapatkan (2006-2016) selalu untuk perluasan lahan. Hasil yang didapatkan dari wakaf produktif unntuk kesejahteraan warga sampai saat ini belum secara signifikan mampu menyejahterakan, walaupun menurut mas Fakhruri warga sudah bisa merasakan sebagai pengelola lahan wakaf dan juga dari hasil dari tanaman tumpang sari yakni pisang. Menurut Mas Musholeh, setelah 10 tahun berjalan, kedepan nya, program wakaf produktif akan dibuat dengan program bagi hasil, sehingga bisa lebih besar manfaat yang akan diperoleh masyarakat dalam meningkatkan kesejahteraan nya.

22 Wawancara dengan mas Musoleh Pegawai Desa Longkeyang sekaligus pengurus Ranting Muhammadiyah Longkeyang tanggal 9 Oktober 2016 jam 13.00

23 Wawancara dengan mas Fakhruri Ketua BP2RM (Badan Pekerja Pengembangan Ranting Muhammadiyah) tanggal 9 Oktober 2016 jam 13.00 
Beberapa hal yang sudah dimanfaatkan dari hasil wakaf produktif:

1. Wakaf kain kafan

2. Suport dana untuk kader yang mau mondok ${ }^{24}$

Walaupun menurut mas Fakhruri belum signifikan, akan tetapi ketika melihat reinstra yang dibuat BP2RM, akan dilihat bagaimana potensi wakaf produktif dari tahun 2010-2028.

\section{Pengembangan Aset Wakaf}

Ilustrasi proyeksi minimal perkembangan aset dari 2010-2028 :

\begin{tabular}{|c|c|c|}
\hline 2010 & $\begin{array}{l}\text { Aset tanah } \\
\text { Aset pohon }\end{array}$ & $\begin{array}{l}: 1750 \mathrm{~m}^{2} \\
: 300 \text { batang berusia lebih } 2 \text { tahun }\end{array}$ \\
\hline \multirow[t]{4}{*}{2013} & Panen & $\begin{array}{l}: 300 \text { pohon } x \text { Rp } 100.000 \text { (harga per batang) } \\
=\operatorname{Rp} 30.000 .000,-\end{array}$ \\
\hline & Beli tanah & $: \frac{\operatorname{Rp} 30.000 .000}{\operatorname{Rp} 15.000 / \mathrm{m}^{2}}=2000 \mathrm{~m}^{2}$ tanah \\
\hline & Aset tanah & $: 1750 \mathrm{~m}^{2}+2000 \mathrm{~m}^{2}=3750 \mathrm{~m} 2$ \\
\hline & Aset pohon & $\frac{3750 \mathrm{~m}^{2}}{6 \mathrm{~m}^{2} / \text { pohon }}=625$ pohon albasia \\
\hline
\end{tabular}

2018 Panen : 625 batang $x$ Rp $100.000=R p 62.500 .000$

Beli tanah $\quad: \underline{\operatorname{Rp} 62.500 .000}=3125 \mathrm{~m}^{2}$ tanah $\mathrm{Rp} 20.000 / \mathrm{m}^{2}$

Aset tanah $\quad: 3.750 \mathrm{~m}^{2}+3.125 \mathrm{~m}^{2}=6.875 \mathrm{~m}^{2}$

Aset pohon $\quad:{\underline{6.875 \mathrm{~m}^{2}}}^{2}=1.145$ pohon albasia $6 \mathrm{~m}^{2} /$ pohon

2023 Panen $\quad: 1.145$ batang $x$ Rp $150.000=\operatorname{Rp~} 171.750 .000$

Beli tanah $\quad: \underline{\operatorname{Rp~} 171.750 .000}=4.294 \mathrm{~m}^{2}$ tanah $\mathrm{RP} 40.000 / \mathrm{m}^{2}$

Aset tanah $\quad: 6.875 \mathrm{~m}^{2}+4.294 \mathrm{~m}^{2}=11.169 \mathrm{~m}^{2}$

Aset pohon $\quad: \underline{11.169 \mathrm{~m}^{2}}=1.862$ pohon albasia $6 \mathrm{~m} 2 /$ pohon

2028 Panen $\quad$ : 1.862 batang $x$ Rp $175.000=\operatorname{Rp} 325.500 .000$

\section{Ranting Muhammadiyah Desa Longkeyang, minimal pada tahun 2028 mempunyai:}

Aset tanah $\quad: 11.169 \mathrm{~m} 2(1$ hektar lebih $)$

Kekayaan (uang) : Rp 325.500.000

24 Wawancara dengan mas Musoleh Pegawai Desa Longkeyang sekaligus pengurus Ranting Muhammadiyah Longkeyang tanggal 9 Oktober 2016 jam 13.00 


\section{Keterangan:}

- Harga tanah di Desa Longkeyang saat ini masih ada harganya dibawah Rp 10.000 per m2.

- Ilustrasi diatas, belum menyertakan hasil aset pohon cengkeh sebanyak 8 batang dimana minimal mendapat hasil Rp 400.000,-/ tahun, 80 (delapan puluh) batang pohon Jabon dan hasil gerakan foundrising yang sedang berjalan melalui gerakan iuran dana abadi, gerakan wakaf pohon, gerakan sedekah produktif abadi dan gerakan tanah produktif.

Dari reinstra (rencana strategis) yang dibuat di atas oleh BP2RM, sungguh sangat potensial pengembangan wakaf produktif Pemuda Muhammadiyah bagi kesejahteraan warga di Longkeyang. Berikut ini beberapa program kerja atau cita-cita yang ingin diwujudkan dari hasil wakaf produktif:

a. 1 Rumah 1 sarjana.

b. Memberikan beasiswa kepada warga Longkeyang untuk menuntut ilmu keagamaan di Timur Tengah untuk memperbanyak kader ulama di Longkeyang.

c. Memberikan beasiswa kepada warga Longkeyang untuk menuntut ilmu kedokteran yang kuliah di kampus terkemuka di Indonesia untuk memperbanyak kader calon dokter di Longkeyang

d. Membangun Pondok Pesantren unggulan. ${ }^{25}$

Selain itu, dari program wakaf produktif Pemuda Muhammadiyah, diikuti organisasi yang lain: dari NU dan Rifaiyah yang juga mengikuti langkah yang sama. Akan tetapi organisasi tersebut, menurut mas Fakhruri tidak seperti Pemuda Muhammadiyah, dimana kedua ormas tersebut, ketika telah memanen hasil dari wakaf, tidak digunakan untuk perluasan lahan, akan tetapi untuk membangun masjid dan hal-hal yang bersifat konsumtif walaupun bermanfaat. Sehingga seakan-akan, hasil wakaf nya sekali panen, langsung habis. ${ }^{26}$

\section{Kesimpulan}

Dari pembahasan tentang peranan wakaf produktif pemuda muhammadiyah di Longkeyang di atas, ada beberapa kesimpulan yang di dapatkan:

\section{Langkah awal gerakan wakaf produktif Pemuda Muhammadiyah di Longkeyang}

a. Adanya kegelisahan warga dan pemuda Muhammadiyah dengan organisasi yang stagnan dan juga seiring sejalan beberapa tokoh ulama yang meninggal dunia, sehingga ada kekhawatiran "kalau sebentar lagi Muhammadiyah di Longkeyang bakal habis" sebagaimana cibiran dari masyarakat lainnya.

b. Membentuk Badan Pekerja Pengembangan Ranting Muhammadiyah (BP2RM) Desa Longkeyang

c. Gerakan Wakaf Recehan Untuk Wakaf Produktif

25 Wawancara dengan mas Fakhruri Ketua BP2RM (Badan Pekerja Pengembangan Ranting Muhammadiyah) tanggal 9 Oktober 2016 jam 13.00

26 Wawancara dengan mas Fakhruri Ketua BP2RM (Badan Pekerja Pengembangan Ranting Muhammadiyah) tanggal 9 Oktober 2016 jam 13.00 
2. Manajemen pengelolaan wakaf produktif Pemuda Muhammadiyah di Longkeyang

a. Dari wakaf recehan yang terkumpul kemudian dibelikan tanah $1.500 \mathrm{~m}$ dimaksimalkan sebagai modal awal.

b. Tanah wakaf yang ada digarap secara bersama-sama untuk menekan biaya dengan tanaman utama kayu albasia, kemudian untuk biaya perawatan menggunakan hasil dari tanaman tumpang sari pisang.

c. Kedepannya, wakaf produktif akan dikelola dengan sistem bagi hasil, karena sejak dari 2006-2010 hasil wakaf produktif pohon digunakan untuk proses perluasan lahan.

3. Peranan Wakaf Produktif Pemuda Muhammadiyah Untuk Kesejahteraan Warga Di Longkeyang

a. Hasil dari wakaf produktif ini, memang belum signifikan, akan tetapi warga sudah bisa merasakan sebagai pengelola lahan wakaf dan juga dari hasil dari tanaman tumpang sari yakni pisang.

b. Beberapa program yang telah dihasilkan dari pengelolaan wakaf produktif yakni wakaf kain kafan adan support dana untuk kader yang mau mondok.

c. Adapun program yang dicita-citakan ke depannya dari hasil wakaf produktif yang dijalankan antara lain:

- 1 Rumah 1 sarjana.

- Memberikan beasiswa kepada warga Longkeyang untuk menuntut ilmu keagamaan di Timur Tengah untuk memperbanyak kader ulama di Longkeyang.

- Memberikan beasiswa kepada warga Longkeyang untuk menuntut ilmu kedokteran yang kuliah di kampus terkemuka di Indonesia untuk memperbanyak kader calon dokter di Longkeyang

- Membangun Pondok Pesantren unggulan

\section{BIBLIOGRAFI}

Abi Bakr Muhammad Ibn al Syarkhasi, Kitab Al-Mabsuth, Beirut: Dar al Kutub al-Ilmyah, Jld. IV Juz XII. Tth.

Ali, M. D. Sistem Ekonomi Islam Zakat dan Wakaf. Jakarta: UI-Press. 1988.

Amin, M., Sam, M. I., AF., H., Hasanuddin, \& Sholeh, A. N. Himpunan Fatwa Majelis Ulama Indonesia sejak 1975. Jakarta: Erlangga. 2011.

Al-Barry, M. Dahlan. Y, dan Yacub, L.Lya Sofyan, Kamus Induk Istilah Ilmiah, Surabaya: Penerbit Target Press. 2003.

Departemen Agama RI, Pedoman Pengelolaan dan Pengembangan Wakaf. Departemen Agama 
Islam Direktorat Jenderal Bimbingan Masyarakat Islam Direktorat Pemberdayaan Wakaf, Jakarta, 2006.

Djunaidi, Ahmad, dkk, Strategi Pengembangan Wakaf Tunai di Indonesia, Jakarta: Direktorat Pengembangan Zakat dan Wakaf Depag RI. 2008.

Emir, Metodologi Penelitian Kualitatif: Analisis Data, Jakarta: PT Raja Grafindo Persada. 2012. Hendi Suhendi. Fiqih muamalah. PT Rajagrafindo Persada. Jakarta, 2008.

Imam Bukhari, Shahih al-Bukhari: Bab al-Syuruth fil Waqaf, Juz: 10. Hadis no. 2737.

Imam Muslim, Shahih Muslim: Bab Ma Yalhaqu al-insan min al-Tsawab, Juz: 11, Hadis no. 4310 .

Jaih Mubarok, Wakaf Produktif, Bandung: Simbiosa Rekatama Media. 2008.

Kememterian Agama Bimas Islam. Paradigma Baru Wakaf di Indonesia. Jakarta. 2013.

Moloeng, Lexy J, Metodologi Penelitian Kualitatif, Cet. ke-14, Bandung : Remaja Rosda Karya. 2001.

Suryana, A. T., Alba, C., Syamsudin, E., \& Asiyah, U. Pendidikan Agama Islam untuk Perguruan Tinggi. Bandung: Tiga Mutiara. 1996.

Wawancara dengan Bpk Casroni sebagai inisiator gerakan wakaf produktif di Longkeyang, 10 Mei 2016, di Desa Longkeyang.

Wawancara dengan mas Musoleh Pegawai Desa Longkeyang sekaligus pengurus Ranting Muhammadiyah Longkeyang tanggal 9 Oktober 2016 jam 13.00

Wawancara dengan mas Fakhruri Ketua BP2RM (Badan Pekerja Pengembangan Ranting Muhammadiyah) tanggal 9 Oktober 2016 jam 13.00. 
